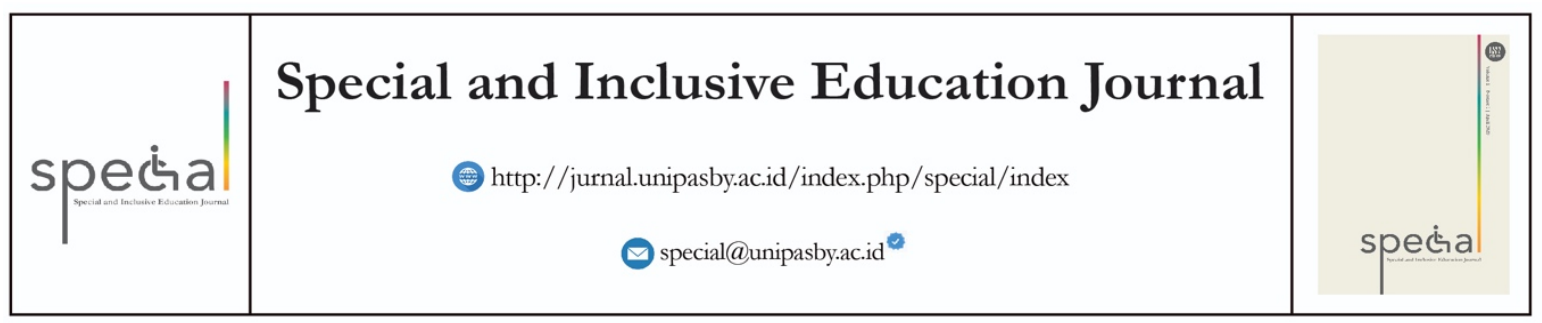

\title{
Efektifitas Role Playing Dalam Meningkatkan Perilaku Prososial Anak Dengan Hambatan Sosial Emosi
}

\author{
Mirnawati \\ mirnawati.plb@ulm.ac.id
}

Pendidikan Luar Biasa/Pendidikan Khusus - Universitas Negeri Lambung Mangkurat

Jl. Brigjen H. Hasan Basri, Pangeran, Kec. Banjarmasin Utara, Kota Banjarmasin, Kalimantan Selatan, 70123

\begin{tabular}{l}
\hline Artikel Info \\
\hline Koresponden penulis : \\
Mirnawati \\
mirnawati.plb@ulm.ac.id
\end{tabular}

- Diterima 21 Januari 2020

- Direview 2 Maret 2020

- Disetujui 3 Maret 2020

- Dipublikasi 29 April 2020

\section{Kata Kunci:}

Anak Dengan Hambatan Sosial Emosional (tunalaras), Sekolah Inklusi, Perilaku Prososial, Role Playing.

Keywords:

Children With Social

Emotional Disorder, Inclusive

School, Prosocial Behavior,

Role Playing

\begin{abstract}
Absstrak
Anak dengan gangguan sosial emosi (tunalaras) mengalami permasalahan untuk berinteraksi sosial terhadap lingkungannya, tapi bukan berarti mereka tida mampu melakuan hubungan sosial dengan orang lain. Penelitian ini dilakukan terhadap gangguan social emosional yang masih memiliki emosi yang belum stabil sehingga mudah sekali tersulut amarahnya hanya karena hal-hal kecil saja namun ia mampu berhubungan soaial dan keterikatan satu sama lain. penelitian ini bertujuan untuk meningkatkan perilaku prososial anak tunalaras melalui kegiatan bermain peran. Penelitian ini menggunakan pendekatan kuantitatif dengan jenis penelitian subjek tunggal (SSR). Desain dalam penelitian ini adalah A-BA. Subjek dalam penelitian ini adalah anak gangguan sosial emosi berumur 13 tahun yang duduk di kelas III SDN Inklusif Benua Anyar 4 Banjarmasin. Sistem pencatatan data menggunakan observasi langsung atau pencatatan kejadian terhadap kejadian atau perilaku yang terjadi dalam periode waktu tertentu. Teknik analisis data dalam penelitian ini adalah analisis visual dalam kondisi dan analisis visual antar kondisi. Hasil penelitian menunjukan mean level Kemampuan perilaku prososial anak pada baseline $1\left(\mathrm{~A}_{1}\right)$ adalah 5 (lima), fase intervensi (B) adalah 14 (empat belas), dan pada fase baseline $2\left(\mathrm{~A}_{2}\right)$ adalah 9 (sembilan), dapat terlihat dari mean level ada peningkatan terhadap perilaku prososial anak dengan gangguan sosial emosi melalui kegiatan bermain peran di SDN Inklusif Benua Anyar 4 Banjarmasin.

Abstarct
Children with social-emotional disorders have problems interacting
socially with their environment, but that does not mean they are unable to
carry out social relationships with others. This research was conducted on
social-emotional disorders that still have emotions that are not yet stable
so it is easy to ignite his anger just because of small things but he can relate
social problems and attachment to one another. This research aims to
improve the prosocial behavior of children with physical disabilities
through role-playing activities. This study uses a quantitative approach to
the type of single-subject research (SSR). The design in this study is A-B-
A. Subjects in this study were 13 -year-old social-emotional disorder
children who sat in class III SDN Inclusive Anua 4 Banjarmasin. The Data
recording system uses direct observation or recording events against
events or behavior that occur within a certain period. Data analysis
techniques in this study are visual analysis of conditions and visual analysis
between conditions. The results showed the mean level of child prosocial
behavior ability at baseline 1 (A1) was 5 (five), the intervention phase (B)
was 14 (fourteen), and in the baseline phase 2 (A2) was 9 (nine), it could
be seen from the mean level is an increase in the prosocial behavior of
children with emotional social disorders through role-playing activities in
SDN Inclusive Inua Anyar 4 Banjarmasin
\end{abstract}




\section{PENDAHULUAN}

Anak dengan hambatan sosial emosi (Anak tunalaras) adalah individu yang mengalami hambatan dalam mengendalikan emosi dan kontrol sosial. Individu tunalaras biasanya menunjukkan perilaku menyimpang yang tidak sesuai dengan norma dan aturan yang berlaku di sekitarnya. Peraturan Pemerintah No. 72 tahun 1991 disebutkan bahwa tunalaras adalah gangguan atau hambatan atau kelainan tingkah laku sehingga kurang dapat menyesuaikan diri dengan baik terhadap lingkungan keluarga, sekolah dan masyarakat. Sementara itu masyarakat lebih mengenalnya dengan istilah anak nakal.

Anak tunalaras mengalami hambatan dalam berinteraksi sosial dengan orang lain atau lingkungannya, tetapi bukan berarti mereka tidak memiliki kemampuan untuk membentuk hubungan sosial dengan semua orang. Banyak kajian yang menyatakan bahwa ternyata mereka dapat menjalin hubungan sosial yang sangat erat dengan teman-temannya. Seperti observasi yang dilakukan oleh peneliti terhadap anak tunalaras di SDN Inklusif Benua Anyar 4 Banjarmasin, yang walaupun dikenal sebagai anak nakal ternyata ia mampu membentuk suatu kelompok yang kompak dan akrab serta membangun keterikatan antara yang satu dengan yang lainnya. Namun, ia mengalami penghayatan yang keliru baik terhadap dirinya sendiri maupun lingkungan sosialnya. Dia menganggap dirinya tak berguna bagi orang lain dan merasa tidak berperasaan sehingga muncul kesulitan apabila akan menjalin hubungan dengannya. Anak ini menunjukkan sikap masih memiliki emosi yang belum stabil sehingga membuat mereka mudah sekali tersulut amarahnya hanya dengan hal-hal kecil. Dia juga cenderung berkelompok, dimana dalam kelompok tersebut ada yang berkuasa dan selalu memerintah siswa yang lain dan juga mengganggu siswa yang lain yang lemah, selain itu siswa ini juga mencontek saat ulangan dan mengerjakan tugas. Semua perilaku yang nampak pada siswa tersebut menunjukkan bahwa memang ada penyimpangan perilaku prososial padanya.

Penyimpangan perilaku prososial yang dialami anak tunalaras berdampak negatif bagi dirinya sendiri atau lingkungan sosialnya. Salah satu dampak serius yang iaalami adalah tekanan batin yang berkepanjangan sehingga akan muncul perasaan merusak diri sendiri. Apabila ia kurang mendapatkan perhatian dan penanganan secepatnya maka ia akan semakin terperosok dalam jarak yang memisahkannyadari lingkungan.

Peranan guru dalam membentuk dan mengubah perilaku anak tunalaras dibatasi dengan peranan siswa itu sendiri dalam membentuk dan mengubah perilakunya. Peranan teman sebayanya dalam lingkungan sekolah sangat menunjang motivasi dan keberhasilan pola-pola perilakunya, karena biasanya anak saling mengisi dan membentuk suatu persaingan yang sehat. Berbagai hal dilakukan anak tunalaras sebagai bentuk sosialisasinya, misalnya aktif dalam kegiatan belajar mengajar, kegiatan ekstrakurikuler kelompok belajar, dan sebagainya. Namun adakalanya pengaruh teman sebayanya akan membentuk tingkah laku yang negatif seperti membolos, merokok, melawan guru, dan 
melanggar tata tertib sekolah. Melihat penyimpangan perilaku anak yang harus segera ditangani, maka perlu adanya tindakan untuk memperbaiki dan meningkatkan perilaku prososial anak tunalaras.

Salah satu upaya meningkatkan perilaku prososial siswa tunalaras adalah dengan cara menerapkan kegiatan bermain peran. Menurut Wicaksono \& Naqiyah (2013) disebutkan bahwa metode bermain peran merupakan metode yang dilakukan dengan cara memperagakan suatu kegiatan secara singkat dengan tekanan utama pada karakter atau sifat orang. Siska (2011) menambahkan bahwa metode bermain peran merupakan metode yang sering digunakan dalam mengajarkan nilainilai dan memecahkan masalah-masalah yang dihadapi dalam hubungan sosial dengan orang-orang di lingkungan keluarga, sekolah maupun masyarakat.

Bermain peran memungkinkan anak untuk belajar banyak hal karena anak bebas untuk berekspresi terhadap peran yang dimainkannya tanpa khawatir akan mendapatkan sanksi. Inten (2017) mengatakan bahwa melalui bermain peran anak-anak mecoba mengeksplorasi hubungan antar manusia dengan cara memperagakannya dan mendiskusikannya sehingga secara bersama-sama anak dapat mengeksplorasi perasaan, sikap, nilai dan berbagai strategi pemecahan masalah. Pelaksanaan metode bermain peran dapat dilaksanakan dalam berbagai situasi termasuk di dalam kelas, namun pelaksanaan bermain peran pada anak usia sekolah dasar harus selalu didampingi oleh guru. Melalui permainan peran ini diharapkan anak akan belajar untuk memahami peran yang dimainkannya dan mampu membangun kerjasama dan mampu menyesuaikan diri dengan lingkungan sosialnya. Hasil penelitian yang dilakukan oleh Triardhila (2013) menunjukkan bahwa terdapat perbedaan perilaku prososial yang tidak terlalu besar antara sebelum diberikan metode bermain peran dan setelah diberikan metode bermain peran.

Uraian diatas menunjukkan bahwa kegiatan bermain peran sangat menarik dan cukup mudah diterapkan, selain itu diharapkan kegiatan bermain peran dapat memberikan pengaruh positif dalam upaya meningkatkan perilaku prososial anak dalam kurun waktu yang telah ditentukan. Maka dalam penelitian ini peneliti meneliti tentang "Upaya Peningkatan Perilaku Prososial Anak Tunalaras Melalui Kegiatan Bermain Peran di SDN Inklusif Benua Anyar 4 Banjarmasin”.

\section{METODE PENELITIAN}

Pendekatan yang digunakan dalam penelitian ini adalah pendekatan kuantitatif dengan jenis penelitian Single Subject Research (SSR) desain A-B-A yang dilakukan sebanyak 15 sesi. Tempat penelitian di SDN Inklusif Benua Anyar 4 Banjarmasin dengan subjek penelitian seorang anak dengan hambatan sosial emosi (anak tunalaras) berinisial NM kelas III. Sistem pencatatan data menggunakan observasi langsung atau pencatatan kejadian terhadap kejadian atau perilaku yang terjadi dalam periode waktu tertentu dan dokumentasi berupa gambar atau foto aktifitas penelitian. Teknis analisis data menggunakan statistik deskriptif yang dipaparkan dalam analisis visual dalam kondisi dan antar kondisi. Instrumen penelitian yang digunakan adalah lembar observasi terkait kemunculan perilaku 
prososial yang ditunjukkan oleh subjek penelitian sesuai dengan indikator perilaku prososial yang divisualisasikan dalam tabel berikut:

Tabel 1. Indikator perilaku prososial

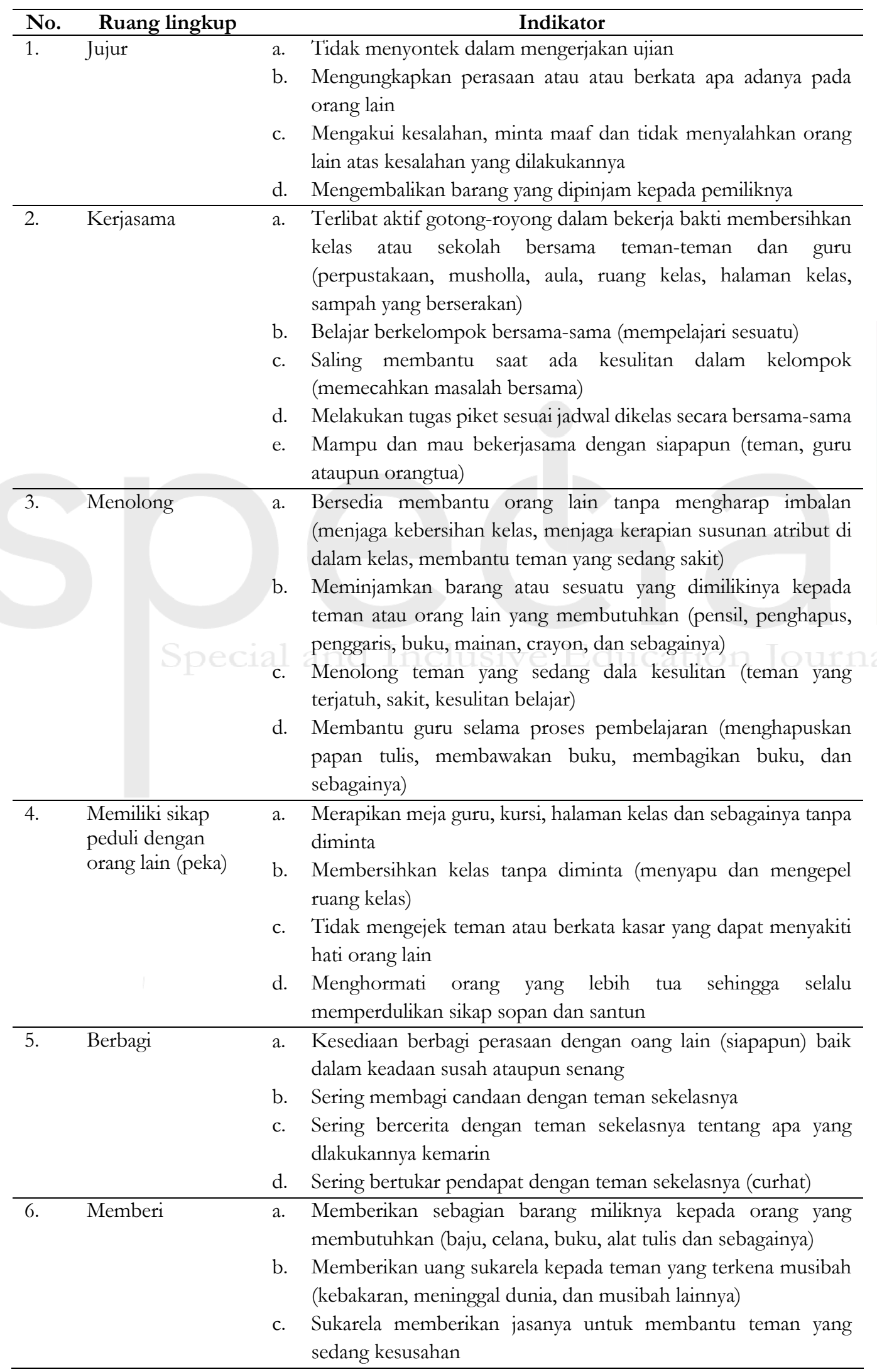




\section{HASIL DAN PEMBAHASAN}

Subjek penelitian merupakan anak tunalaras di kelas III SDN Benua Anyar Banjarmasin dalam penelitian ini. Anak ini mempunyai hambatan dalam perilakunya sehingga tidak atau kurang dapat membangun hubungan yang harmonis dengan teman sebaya ataupun dengan orang dewasa. Penyimpangan perilaku yang ia lakukan tentunya bertentangan dengan nilai dan norma yang berlaku dilingkungan tempat ia berada. Sehingga secara pedagogis memerlukan adanya pelayanan pendidikan dan bimbingan secara khusus. Terhambatnya kemampuan berinteraksi sosial yang baik berimplikasi pada kebutuhan khusus mereka untuk mengembangkan kemampuan sosialnya dengan metode atau kegiatan khusus, yang merupakan dasarnya setiap siswa tunalaras dapat dikembangkan kemampuan sosialnya melalui berbagai layanan khusus dan fasilitas khusus sesuai dengan kebutuhannya.

Berperilaku sosial yang baik tidak semudah seperti halnya siswa pada umumnya. Sebagai akibat tidak bisa berinteraksi sosial baik dengan lingkungannya dapat berdampak pada lingkungan sosialnya. Sehingga ia akan memiliki keterbatasan dalam berinteraksi sosial, ia tidak atau kurang mendapatkan respon yang baik dari lingkungan sosialnya. Agar anak tunalaras bisa mendapatkan respon yang baik dari lingkungan sosialnya maka perlu adanya kegiatan untuk memperbaiki dan melatih interaksi sosialnya. Salah satunya adalah dengan bermain peran.

Pada tahap baseline $1\left(A_{1}\right)$ memperoleh mean level 5. Dilihat dari hasil diatas, akan sangat wajar jika hasil yang ditunjukkan oleh anak masih rendah karena pada fase ini tanpa ada perlakuan apapun. Hal ini sejalan dengan teori bahwa tunalaras adalah anak yang menonjol berinteraksi terhadap lingkungannya dengan cara yang secara sosial tidak dapat diterima atau secara pribadi tidak menyenangkan tapi masih dapat diterima oleh dirinya ataupun orang lain.

Sejalan dengan teori yang dikemukakan oleh Sumarna (2013) bahwa tunalaras adalah anak yang secara kronis dan mencolok berinteraksi dengan lingkungannya dengan cara yang secara sosial tidak dapat diterima atau secara pribadi tidak menyenangkan tapi masih dapat diterima. Selain itu juga sejalan dengan teori yang dikemukakan oleh Sechmiddan Mercer (1981) dalam Hidayat (2013) yaitu anak tunalaras adalah anak yang secara kondisi dan terus-menerus menunjukkan penyimpangan tingkah laku tingkat berat yang mempengaruhi proses belajar meskipun telah menerima layanan belajar serta bimbingan seperti anak lainnya.

Pada fase intervensi (B) mean level kemampuan perilaku prososial subjek adalah 14. Intervensi berguna untuk mengetahui potensi anak (Irvan \& Jauhari, n.d.) Fase ini sudah diberikan perlakuan berupa kegiatan bermain peran. Asih \& Pratiwi (2010) menyatakan "bermain peran merupakan sebuah metode pembelajaran yang berasal dari dimensi pendidikan individu maupun sosial". Metode ini membantu masing-masing siswa untuk menemukan makna pribadi dalam dunia sosial mereka dan memecahkan dilema pribadi dengan bantuan kelompok. Dalam dimensi sosial, metode ini bermanfaat 
memudahlan individu untuk bekerjasama dalam menganalisis kondisi sosial, khususnya masalah kemanusiaan. Dalam metode bermain peran anak tunalaras dapat mengungkapkan dan menyampaikan informasi yang ia dapat sehingga anak tunalaras dapat berkomunikasi dengan baik dengan teman-temannya dan orang lain di sekitarnya. Bandura menyebutkan jika proses melihat, mengamati, meniru perilaku dan sikap orang lain sebagai contoh merupakan tindakan belajar. Artinya seseorang akan mudah meniru perilaku yang dicontohkan orang lain daripada ia harus belajar sendiri dan pembiasaan sendiri. Olson \& Hangerhahn (2009) dalam Sugianto (2015) mengemukakan bahwa dalam konteks sosial, manusia akan terus mengembangkan proses belajar yang melibatkan kognitif dan standar penilaian perilaku oleh lingkungan.

Pada fase baseline 2 (A2) mean level kemampuan perilaku prososial subjek adalah 9. Fase ini merupakan fase kontrol untuk mengetahui pengaruh dari intervensi yang diberikan. Hal ini terjadi karena pengaruh lingkungan terhadap subjek, standar penilaian lingkungan terhadap perilaku yang dibiasakan terhadap subjek, pembiasaan-pembiasaan, stimulasi serta motivasi yang diberikan selama fase intervensi yang memberikan dampak positif pada subjek. Selain itu juga karena dukungan dari lingkungan dan apa yang ia lihat sehingga ia mampu mencontohkan perilaku yang lebih bisa diterima oleh lingkungannya. Ia mampu belajar dari lingkungannya dan mampu mengaplikasikannya. Perilaku sosial yang dapat diterima masyarakat dipandang sebagai perilaku yang memberikan efek positif dalam masyarakat, seperti menolong, berbuat baik, atau disebut dengan perilaku prososial, dan perilaku sosial yang tidak dapat diterima dipandang sebagai perilaku yang memberikan efek negatif dalam masyarakat atau disebut dengan perilaku antisosial (Baumeister \& Bushman, 2011).

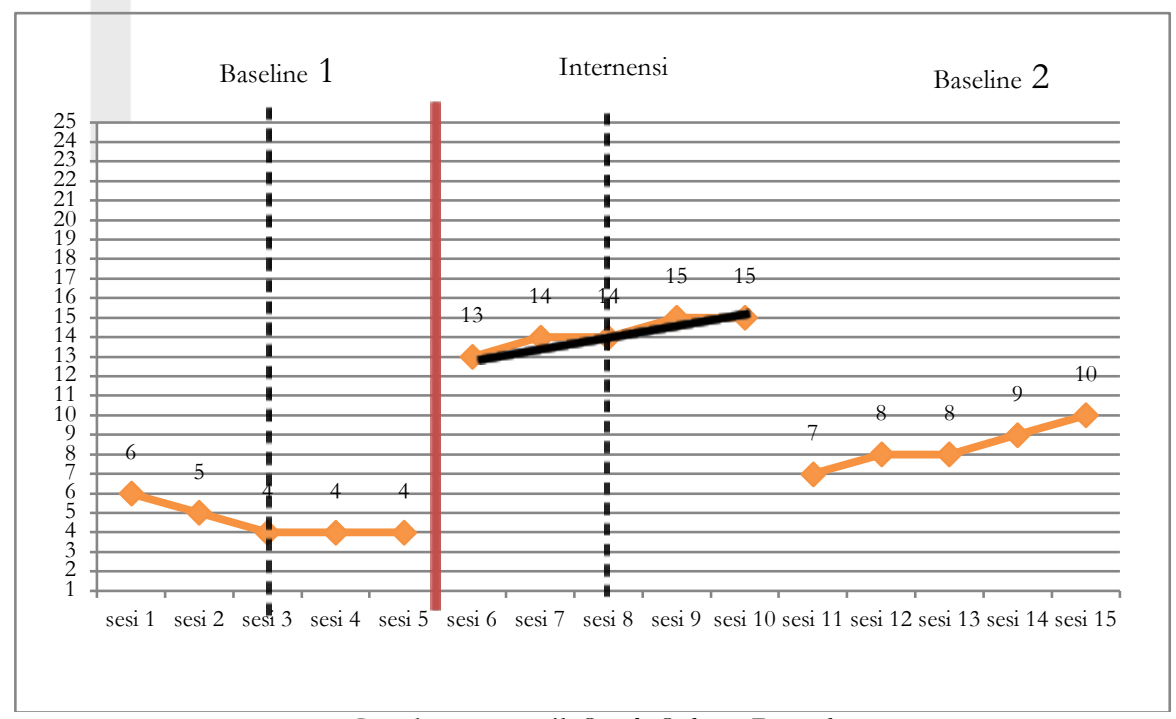

Gambar 1. Hasil Single Subjuct Reserch

\section{KESIMPULAN}

Pembahasan hasil penelitian menunjukkan bahwa kegiatan bermain peran dapat meningkatkan perilaku prososial anak dengan hambatan sosial emosi (anak tunalaras) di SDN Inklusif Benua Anyar 4 Banjarmasin 


\section{DAFTAR PUSTAKA}

Asih \& Pratiwi. (2010). Perilaku Prososial ditinjau dari empati dan Kematangan Emosi. Jurnal Psikologi

Baumeister, R. F., \& Bushman, B. J. (2008). Social psychology \& human nature. Belmont, CA: Thomson Higher Education.

Elyana. (2016). Pengaru Penggunaan Metode Bermain Peran Makro terhadap Perilaku Prososial Anak Usia 5-6 Tahun di TK Kesuma Segalamider Tanjung Karang Barat Tahun Ajaran 201/2016. 29-31.

Hidayat, Wawan. (2013). Pendidikan Anak Berkebutuban Khusus Tunalaras Peserta Didik Berkebutuban Khusus dengan Hmbatan Perilaku Emosi dan Sosial. Jakarta Timur: PT. Luxima Metro Media.

Inten, D. N. (2017). Pengembangan Keterampilan Berkomunikasi Anak Usia Dini Melalui Metode Bermain Peran. Mediator: Jurnal Komunikasi, 10(1), 109-120.

Irvan, M., \& Jauhari, M. N. (n.d.). Early Intervention For Children With Autism Spectrum Disorder Using Planning Matrix.

Siska, Y. (2011). Penerapan Metode Bermain Peran (Role Playying) Dalam Meningkatkan Keterampilan Sosial Dan Keterampilan Berbicara Anak Usia Dini. Edisi Khusus, (2), 31-37. Sugianto. (2015). Pengaub Pola asub Orang Tua Terhadap Perilaku Prososial Siswa Kelas V SD Segugus Kecamatan Pengasib Kabupaten Kulon Progo Tabun ～Ajaran 2014/2015. 28, 35-40.

Sumarna, Taska. (2013). Bina Pribadi \& Sosial Bagi Anak Berkebutuhan Khusus.Jakarta Timur: PT. Luxima Metro Media.

Triardhila, W. K.N. 2013. Pengaruh metode bermain peran terhadap peningkatan perilaku prososial anak TK A LAB. UM Kota Blitar. Artikel. Universitas Negeri Malang

Wicaksono, G., \& Naqiyah, N. (2013). Penerapan Teknik Bermain Peran Dalam Komunikasi Interpersonal Siswa. Journal Mahasiswa Bimbingan Konseling, 1, 61-78 